\section{Discussão sobre • receptor ativo na Escola de Frankfurt}

Francisco Rüdiger

Doutor em Gèncias Sociais, USP

Professor da FAMECOS/PUCRS e FABICO/UFRGS
A CRITICA A INDUSTRIA cultural frankfurtiana transformou-se no últimos anos numa espécie de espectro que ronda a consciência dos estudiosos da comunicaçāo. Nesse período, a reflexão critica perdeu terreno diante do discurso entusiasta, quer em relação ao progresso técnico, quer em relação ao bom senso das massas.

Chegada a era pós-moderna, vislumbrada de maneira pioneira pelos velhos frankfurtianos, a critica à indústria da cultura parece ter sido jogada às traças pela maior parte dos praticantes dos estudos culturais e pesquisadores da comunicaçầo.

Aparentemente a tendência agora é legitimar a cultura de massa e saudar o advento da sociedade de comunicaçāo. As vésperas do novo milếnio, o recurso à teoria critica passou a soar como um anacronismo ou expediente elitista, carregado de esquematismo e visāo estreita, promovido por modernistas nostálgicos, saudosos da suposta cultura autêntica gestada nos primórdios da era burguesa.

No Brasil, a perspectiva frankfurtiana tornou-se denuncismo rancoroso e discurso depressivo, baseado em uma concepçāo superada da cultura e da midia, metodologicamente desprovida dos meios para compreender as benesses da técnica e as coniradiçôes da sociedade, a cultura no plural e as mediaçōes na comunicação. Os pesquisadores aderiram acriticamente à idéia de que "seu tempo passou [porque] - ainda que possuisse algo relevante a dizer, nós teriamos meios melhores de fazê-lo atualmente. Persistir com o enfoque da Escola de Frankfurt [portanto] é ficar preso a um enfoque que é ao mesmo tempo estreito e ultrapassado" (Strinatti 1995: 52).

O presente texto se origina de um trabalho 
de pesquisa mais amplo - em andamento onde questiono esse consenso e procuro confrontar os juizos correntes sobre as idéias do grupo com a letra do espolio que nos deixou. Segundo nosso modo de ver, a critica à teoria da indústria cultural tornou-se com o tempo uma prática ritual, desprovida de conteúdo vivo, onde repete-se uma série de chavōes e platitudes. A perspectiva frankfurtiana foi transformada em um cadáver que os estudiosos da cultura contemporânea todavia nầo cansam de enterrar, talvez menos para provar por que suas teorias estão vivas do que pelo fato que nela esteja inscrita sua má consciência

Neste ensaio procuraremos - em resumo revisar o entendimento de que a teoria critica procedeu a uma reificação dos sujeitos sociais, enquanto pressuposto da idéia de que nesse modelo "o receptor se encontra reificado por completo" (Wilton, 1995: 20). Defende - a corrente dos estudos culturais, o juizo segundo o qual o paradigma frankfurtiano nâo tem um conceito de público como receptor ativo e criador de significados. Deixando para outra ocasiầo a exposiçăo dos motivos para afirmar porque nầ é bem esse o caso, limitar-nos-emos, nessas páginas, a mostrar porque nâo procede a critica à sua suposta reificaçâo: nesse enfoque se trata o problema do receptor como sujeito.

Costumeiramente atribui-se aos frankfurtianos o entendimento de que a industria cultural realiza um trabalho ideológico de lavagem cerebral nas massas e, assim, as mantém num estado de falsa consciência (alienaçăo). O juizo não condiz com suas idéias mais originais. Algumas vezes Adorno chegou a dizer que a televisão "contribui para divulgar ideologias e dirigir de maneira equivocada a consciência dos espectadores" (Adorno, 1995: pp. 77, 80). As principais referencias à midia como ideologia feitas pelo autor todavia nào se situam nesse plano. "A concessão de reconhecer que os filmes difundem ideologias já é ela mesma uma ideologia difundida", escrevia ele em Minima Moralia (\# 130). As comunicaçòes e a indústria da cultura nâo funcionam com base na transmissăo de ideologia, na medida em que "só se pode falar em ideologia quando um produto espiritual surge do processo social como algo autônomo, substancial e dotado de legitimidade" (Horkheimer e Adomo, 1978: 200).

A peculiaridade dos mecanismos de integração contemporáneos provém do fato de que eles năo funcionam com base na ideologia. O principio de integração que se impóe na sociedade atual reside na própria forma da mercadoria (Cf. Honneth, 1991: 95), Costuma-se pensar que a midia tem um caráter ideológico porque veicula certos conteúdos. No enfoque em juizo não se passa dessa maneira. O problema da ideologia está antes no significado que o próprio meio passou a ter na vida das pessoas, na relação das pessoas com esse meio enquanto aspecto do chamado véu tecnológico.

Conforme Adorno chama a atenção, contrariamento ao suposto por seus criticos, a aparelhagem cultural moderna lida com uma "audiência desiludida, alerta e dificil de convencer" (1991: 139). A civilização moderna näo fez os homens senhores de sua vida. No entanto os tirou da alienaçào. A subjetivização da razà̃o tornou-os mais conscientes de sua situação, e os avanços nos meios de informação ampliaram seus conhecimentos. O esclarecimento desencantou os homens e o mundo; expulsando-os do "jardim mágico" em que viviam, para usar a expressão de Weber. A proposiçào inclui as relaçōes que acabam travando na esfera da indústria cultural.

Embora estejam cada vez mais enredados em seus mecanismos, os individuos, em sua maioria, realmente năo crêem que ali se decida seu destino. A verdade é que, no fundo, "as massas não vêem e aceitam de há muito o mundo tal como thes é preparado pela indústria cultural" (1886: 98). 
Durante algum tempo, "fizemos, todos nós, a suposiçầo de que, até certo ponto, a indústria da cultura atual, a qual devemos atribuir todos os poderes de integraçào social em sentido amplo, realmente condiciona, conforma ou pelo menos conserva os indivíduos tal como sầo. No entanto, nesta afirmaçào se esconde algo realmente dogmático e nấo comprovado. Se há algo que aprendi no curso dos últimos anos é que não se pode atribuir esta identidade entre os estimulos e estruturas objetivas que condicionam os individuos e a sua conduta" (Adorno, 1996:200)

No entendimento do autor, o movimento da indústria cultural precisa ser visto de maneira histórica e dialética, observando-se que somente "se nầo tivessem sobrevivido muitos residuos do periodo pré-monopolista que estão em desacordo com a indústria da cultura e dos bens de consumo, residuos esses que os homens devem voltar a levar em conta, [é que] estaria realizada há algum tempo aquela situaçâo de utopia negativa, sobre a qual ironizam com prazer os escritores que nào querem a positiva" (1976: 235 ).

Na modernidade avançada, a dominação pessoal praticamente desapareceu e cedeu lugar a dependência aos mecanismos técnicos, cuja pressāo é cada vez mais consciente aos individuos. A racionalizaçăo dos sistema de dominaçào leva-a a ser exercida de maneira anònima e pontual na empresa, na escola, no hospital e nos serviços públicos. Verifica-se o surgimento de uma dominaçầ anônima e dispersa, através da qual se mantém a sujeiçâo dos seres humanos ao sistema de vida capitalista.

As mercadorias culturais tecnológicas são a principal mediação desse processo, correspondem à concepçào de mundo segundo a qual se poderia construir a sociedade diretamente a partir da tecnologia. A tecnologia e o mercado, onde podemos adquiri-la, podem resolver todos os problemas da vida, do homem e da sociedade.
A civilizaçāo produz pessoas raciona is que tendem a ser mais dificeis de iludir, mas por outro lado tendem a se deixar fetichizar pelas mercadorias culturais da indústria. Os individuos tendem a desenvolver uma atitude exagerada e irracional para com os automoveis, computadores, tênis e outros bens de consumo. A sociedade nào sabe "onde se encontra o limiar de uma atitude racional para com ela e a citada supervalorizaçăo" (Adorno, 1986: 42).

O racionalismo é causador de uma irracionalidade, segundo a qual tudo tem soluçào técnica. Os eletrodomésticos văo nos fazer mais felizes; os computadores, redimir o atraso educacional; os servicos telefónicos, nos tirar da solidão e, a medicina, descobrir o segredo da vida eterna - sem cogitar a hipótese de que a eternidade nào será menos problemática do que o ser-para-a-morte (Heidegger).

Adomo nota que, vista mais de perto, essa visão todavia é mais ideológica do que todas as outras anteriores, Basicamente ela cobre com um véu o fato de que os problemas sociais são criados pelos homens e, em tese, só eles podem eliminá-los, sob dadas condiçōes. A transferência das faculdades humanas da práxis para a tecnologia é ideológica porque, realmente, a tecnologia se tornou um denominador comum em todas as esferas e assim permite às pessoas crer que têm resposta para seus problemas, mas também porque essa crença é falsa: a tecnologia nâo somente serve aos interesses politicos e económicos dominantes como obedece a uma regularidade cega e irracional, criadora de grandes riscos, que nâo tem os poderes apregoados e encontra sua expressāo em uma ansiedade "onipresente e livremente flutuante" (Adorno 1986: 74).

A transformaçāo da tecnologia em ideologia entretanto significa uma mudança de sentido no conceito dessa última porque essa nova crença se reduz cada vez mais a afirmação do individuo e do mundo pura e 
simplesmente como sāo em nossa sociedade. Ao contrários dos fetiches, as crenças sempre tiveram como objeto as ideias. $\mathrm{Na}$ atualidade acontece de os valores e idéias serem coisificados nas mercadorias culturais tecnológicas, A confiança social no valor das idéias e a crença em sua realizaçâo cederam lugar ao realismo desencantado e à descrença em verdadeiros ideais. "Os valores perderam sua substância" e "são cada vez menos motivo de crença" (Adorno 1991:141).

A autoconsciência dos contemporâneos rejeitou o idealismo. Os individuos sabem que as idéias valem muito pouco. Realmente, contam apenas os interesses, seu eu e as coisas tangiveis que podem manipular de maneira objetiva. As estruturas ideológicas que modelavam a consciência perderam caráter autônomo, passando a se confundir com a cultura material, Entretanto, porque nào acreditam mais em idéias, "tornou-se cada vez mais dificil persuadir as pessoas a colaborar" (Horkheimer e Adorno, 1985: 135). A sobrevivência no interior do sistema que a tudo abarca levou-as a renunciar a viver de acordo com sua aptidāo e a se resignarem com as necessidades que podem ser saciadas de acordo com sua situaçào no mercado. As exceçōes continuam a ser privilégio de uma pequena camada social.

O conformismo nāo significa porém que acreditem no sistema, na medida em que o modo de ser da vida social se tomou transparente. Resumidamente, os fenômenos ideológicos assumiram o contorno de um vều tecnológico, porque se por um lado os homens aceitam a mentira que se tornou sua vida, por outro conseguem enxergar sem ilusôes essa realidade (Horkheimer e Adorno, 1978: 203).

A industria cultural faz parte desse véu tecnológico: "O poderio social que os espectadores adoram é mais eficazmente afirmado na omnipresença do esterótipo imposta pela técnica do que nas ideologi- as rançosas pelas quais os conteúdos efemeros devem responder" (Horkheimer e Adorno, 1985: 127). O capitalismo dissolveu as formaçòes espirituais. $\mathrm{A}$ indústria da cultura é uma expressāo do agnosticismo desorientado resultante desa situação, é uma mediação através das qual se articula a consciência $e$ a inconsciência das massas no capitalismo avançado.

Adorno afirma várias vezes que o principal mecanismo em que se baseia a indústria cultural é o da identificação. "Os programas radiofónicos, os shows de televisào e os filmes, sobretudo, se caracterizam por mostrarem heróis, pessoas que de maneira positiva ou negativa resolvem seus própios problemas. O espectador vê a si mesmo neles. Devido a sua identificaçào com o herói, supōe participar da suficiência que the foi negada [na sociedade]" (Adorno, 1986b; 37).

Pesquisando mais a fundo nota-se porém que essa identificação năo tem verdadeiro significado psicológico, corresponde antes a uma espécie de aplicação da concepçāo dramatúrgica da vida social que se encontra no escritos de Goffman. Na sociedade de massa o âmbito da vida psiquica é cada vez mais limitado pelo pragmatismo. O característico não é a comunhão, mas "a incapacidade de identificaçâo" (Adorno, 1986: 43). O espirito gregário vigente é uma reação à situaçào objetiva. Os individuos realmente nào se identificam com as personagens $\mathrm{e}$ modelos de conduta veiculados pelas comunicaçòes.

Para Adorno as pessoas se espelham neles mas de fato näo há mimesis: apenas encenam essas situaçōes; fazem de conta que sua vida pode ser semelhante. A artificialidade das celebridades e situaçóes criadas pela indústria da midia tornou-se de amplo conhecimento público e asim projetam-se sobre as pessoas como simples performance. As pessoas sabem que o que se passa nos programas, anúncios e filmes que assistem não é factivel mas publicidade, cinema ou 
televisào. Na realidade as coisas näo se passam como no cinema. A conduta pode ser comparada com aquela que tem lugar durante sessão de hipnose: trata-se de uma situação em que as pessoas deixam se lograr para obter certa gratificação, Os individuos conservam a consciência de que se trata de um truque, que se joga com sua anuência e que ele mesmo não vai fazer nada contra a sua vontade.

A subjetividade e os costumes são submetidos a todo tipo de manipulação - e todos sabem disso, embora nāo em toda a sua extensào. Os individuos têm consciência de que são alvo da publicidade, embora sem saber até que ponto se tornaram produto dela, assumindo perante a mesma uma postura de reserva, suspeita ou desconfiança. A complascência dos intelectuais com o entretenimento popular se reflete nas massas, "à medida em que a consciência dos consumidores está cindida entre o gracejo regulamentar, que prescreve-the a industria cultural, e uma nem mesmo muito oculta dúvida de seus beneficios" (Adorno, 1986: 96).

A formaçăo de contra-públicos preconizada por muitos intelectuais progressistas é um processo inscrito nas condiçōes históricas e sociais de existência da indústria cultural $e_{\text {, }}$ por isso, não surpreende que nos últimos anos a cultura da midia venha dando lugar a personagens e situaçōes cujo caráter fraudulento e hiperbólico não thes permite servir de modelo, servem apenas para que o público se divirta com a paródia de si mesmo - que se tornou um dos modelos de conduta em ascensăo com o surgimento do populismo pós-modernista (Cf. Hansen, 1992: 71-73).

O capitulo sobre a indústria cultural ainda nâo havia sido escrito, mas já se chamava a atençāo para o fato de que as massas possuem uma atitude "ambigua para com a manipulaçăo". Os individuos sabem que os veiculos de comunicação passam por um processo de concentraçăo econômica, que afeta a formação da opiniào pública. As estratégias empregadas pelos controladores da indústria cultural conflita com um temor crescente e universal para com a possibilidade de que isso se traduza em manipulação. Trata-se de uma atitude que "começa com a resistência às vendas e termina na crença semi-consciente de que nenhuma palavra dita em público tem sentido objetivo ou mesmo expressa as conviç̧ồes privadas do individuo" (Adorno, 1975: 15-16).

Segundo Horkheimer e Adorno, a explicaçà para tanto deve ser buscada no processo civilizador moderno, que ensejou o surgimento de uma consciência dividida. Atualmente as pessoas ao mesmo tempo se distraem e conservam uma postura realista diante do mundo. $\mathrm{O}$ individuo contemporâneo é ao mesmo tempo esclarecido e supersticioso, calculista e irracional, individualista e desejoso de ser como os outros. O reflexo disso é o seguinte: "Por um lado, os individuos obedecem os mecanismos de personalizaçâo, tal como são dirigidos pela indústria cultural; mas por outro [...] sabem que isșo nầo é o importante" (1996: 200).

A corrroboração da hipótese, sugerida bastante cedo, surgiu ao longo de diversas pesquisas conduzida pela equipe do Instituto de Pesquisas Sociais.

Desde o inicio, os criticos da indústria da cultura advertiram que os astudos de conteudo "proporcionam formulaçōes cuja validez somente pode e deve ser definida pesquisando [o receptor]" (Adorno, 1986b: 15). A postulação dos efeitos peculiares de um bem cultural supunha a superação das análises de conteúdo mais antigas, que necessariamente partiam demasiado da intenção dos filmes, nāo considerando suficientemente a amplitude de variaçâo entre esta e o efeito" (Adorno, 1986: 102). Resumidamente entendiam que "quaisquer que sejam as reaçōes do espectadores frente a televisão atual, essas só poderiam ser estabelecidas ostensivamente mediante uma investi- 
gaçâo mais detalhada com os espectadores" (Adorno, 1974: 69).

A pretendida identidade entre industria cultural e indústria da consciência (Adorno, 1986: 70) é válida, desde que se esteja ciente de que esta formula é falsa e verdadeira. E verdadeira e falsa ao mesmo tempo porque, embora a experiencia individual seja esquematizada pelo processo, jamais se produz uma total identidade entre ela e a consciència do individuo. Portanto "a identidade de ambas nầo está tấo açima de toda e qualquer dúvida como imagina o intelectual crítico, enquanto ele fica do lado da produção, sem examinar empiricamente o lado da recepção" (Adorno, 1986: 106).

Aparentemente os críticos da indústria da cultura concluiram que os homens e a indústria se adequam entre si, mas cabe duvidar desta equação, que nào expressa seu uiltimo ponto de vista sobre a matéria. Observacoes feitas ao acaso haviam sugerido que as leitores das colunas de horóscopo dos jornais relutam em leva-las a sério e adotam uma atitude irônica para com seu proprio hábito. Noutros termos, "as aceitam com o que poderia definir-se de reserva mental, um certo jogueteio que consiste em reconhecer com indulgência a irracionalidade básica da astrologia e a aberraçāo em que eles mesmos incorrem ao procurá-la" (Adorno, 1986b: 30)

O estudo sobre a recepsẫo da cobertura que a midia alemã deu às festas nupciais de figuras da nobreza européia, entre outros, demonstrou que diversas pessoas "observavam uma conduta realista e avaliavam com sentido critico a transcendência política e social do acontecimento". Comprovou a idéia de que "as pessoas consomem e aceitam realmente o que industria cultural thes propôe durante o tempo livre, mas com uma espécie de reserva, semelhante àquela com que mesmo os mais ingenuos negam a realidade dos episódios fornecidos pelo teatro e pelo cinema"
Consequientemente precisamos considerar com toda a seriedade a hipótese de que a integração sistêmica, sempre parcial, nào quer dizer integraçâo da consciência do individuo. O caráter simulado dessa última mas, ao mesmo tempo, a pressão material da primeira, da qual quem quer sobreviver nảo pode fugir, sugerem que a integraça tem um aspecto ideológico. Noutras palavras, significa que, apesar dele, "Os interesses reais do individuo conservam suficiente poder para resistir, dentro de certos limites, a seu total aprisionamento. INote-se de resto que] este fato estaria de acordo com o prognóstico social segundo o qual uma sociedade cujas contradiçōes fundamentais permanecessem inalteradas tampouco poderia integrar-se totalmente na consciência" (Adorno, 1973: 62-63).

As formaçōes ideológicas que circulam socialmente através das mercadorias da indústria nầo são de maneira necessária a de seus clientes (Adomo, 1973: 122). Basicamente é isto que Marcuse pretendeu dizer ao escrever que, atualmente, "os vinculos espirituais entre o individuo e a cultura estao soltos". De todo modo, a lembrança dessa entendimento, por si só, deveria nos pôr em guarda e questionar os juizos segundo os quais os frankfurtianos construiram uma visão impositiva da cultura de massa, reduzindo as comunicaçôes a "um processo unidimensional através do qual a indústria cultural 'manipula' seus consumidores" (Modlewski, 1986: p. x).

No modo de ver desse grupo, as comunicaçôes de massa reforçam as exigências que a sociedade coloca a cada individuo para poder funcionar e para que este funcione conforme ela necessita. No entanto paria que seja assim precisam coadunar-se com suas inclinaçōes. Raramente transmitem algo que seus clientes nāo tenham aprendido antes em sua vida cotidiana. Embora possamos discutir até que ponto são artificiais, as mercadorias culturais são produtos da práxis humana que estão baseadas, antes, na ex- 
ploração do que na negação das aspiraçồes e desejos do individuo.

Em consequèencia disso precisamos rever o juizo segundo o qual a crítica da indústria cultura parece nâo indicar nada mais do que a passividade da audiencia. Adorno tratou-as assim em diversas passagens, chegando ao ponto de dizer que, privados de quaisquer residuos de livre-arbitrio, "os individuos sucumbem sem resistência ao que thes é oferecido" (Horkheimer e Adorno, 1985: 125) e "tendem a produzir reaçóes passivas, tornando-se meros centros de reflexos socialmente condicionados" (1986: 144).

Entretanto no método dialético o momento nào deve ser tomado pelo todo; os juizos năo querem dizer identidade. A passividade das audiência é ideologia (aparência socialmente necessária): significa que as pessoas estão paralisadas, mas não totalmente, O sujeito - por mais reificado que possa estar - continua vivo na esfera da industria da cultura. "A despeito do grau de reificaçăo que possuam na realidade, nenhuma das categorias em foco - cultura e ad ministração - está totalmente reificada; da mesma forma que o mais formidável invento cibernético - ambas remetem ao sujeito vivo (tiving subject)" (Adorno, 1991: 113).

O movimento cultural da indústria năo se reproduz de maneira mecanica: é um processo mediado pelo sujeito. As mercadorias culturais não chegam às pessoas andando com suas próprias pernas. Precisam ser ligados ao sujeito pelo próprio sujeito (Adorno, 1976: 48). As condutas e hábitos em que estão prescritas - assim como as pessoas que nelas se espelham - são produto de um sistema de vida mais amplo, que nàto é aceito sem resistencia interior, exigindo o emprego mais ou menos consciente da vontade para se transformarem em comportamento.

A crescente integraçăo das pessoas que escapam à exclusão é funcional mas năo me- cânica. A propaganda não basta para fazer as pessoas agirem. Conforme nota o autor, os comportamentos de massas nāo são resultado de pura e simples doutrinação pelos meios de comunicação. "A explicação de que os interessados em tal situaçăo controlam todos os meios de opiniào pública, já antiga, não basta por si só agora. As massas nāo se deixariam enganar por uma propaganda burda e falsa, se algo nelas mesmas nào desse acolhida a mensagens que exaltam [até mesmo] o sacrificio e o viver perigosamente" (Adorno, 1976: 35).

A planificação sistemática e distribuição organizada de mercadorias culturais sem dúvida são um fator decisivo: reforçam as condiçōes sociais favoraveis para uma identificaçăo do individuo mutilado pelos processos de trabalho com os modelos de conduta afinados com a produçào de mercadorias. A devoçáo maniaca ao consumo e a vontade com que as pessoas se entregam à sua prática evidenciam porém que há algo mais além nisso tudo. O consentimento com isso tudo de alguma expressa a resistência à reificação, que não pode deixar de ocorrer mesmo no mundo administrado. A subjetividade jamais se deixa reificar totalmente. $O$ individuo continua procurando ele mesmo se fazer sujeito inclusive diante da crescente massificação (Adorno, 1991: 40).

Adorno trata a questão no artigo "Sobre a música popular": "Entusiasmo pela música popular requer deliberada resolução por parte dos ouvintes, que precisam transformar a ordem externa a que são subservientes em uma ordem interna."

O consumo obsessivo da música pop - assim como de outros bens simbólicos - é manipulado pelo sujeito. A corrida à loja de discos, a procura de noticias sobre os astros, a formaçăo de clubes, o comparecimento aos shows, os exercicios de vassalagem pessoal etc. que se vê entre os fàs - tudo isso envolve uma decisāo no sentido de vencer o senso critico. 
"O fã da música popular precisa ser imaginado como percorrendo o seu caminho com olhos firmemente fechados e dentes cerrados a fim de evitar que se desvie daquilo que decidiu aceitar. Uma visão clara e calma colocaria em perigo a atitude que the foi infligida $e$ que, por sua vez, ele tenta infligir a si mesmo." (Adorno, 1986: 144-145)

O esclarecimento não é nem pode ser revogado de maneira arbitrária e mecánica pela indústria da cultura. As performances através das quais os individuos encenam sua pretendida identificação com as condutas que sabem fantasiosas requer seu esforco como sujeitos. Somente dessa maneira eles logram equilibrar as contradiçôes de que sào palco suas vidas e que como tal não se pode abdicar sob pena de se entrar em pânico e cair no vazio subjetivo da desorientaçào. A industria cultural é um processo em que as pessoas se entregam a um feitiço hipnótico socializado: depende de sua vontade em se deixar enganar e năo de uma submissão mecànica.

Portanto, "não podemos nos contentar simplesmente em afirmar que a espontaneidade [individual] foi substituida pela cega aceitaçāo do material imposto" através da industria da cultura (Adorno, 1986: 146). O movimento todo poderoso que emana das mercadorias culturais esquematiza em escala cada vez maior a subjetividade, mas isso "não implica a absoluta eliminação da resistência", conduzida a estratos cada vez mais profundos da alma humana. A reprodução da indústria cultural por parte dos sujeitos é um movimento precário e que carrega consigo as forças que em principio poderiam livrá-lo do feitiço a que voluntariamente se entregam, dentro de condiçōes históricas determinadas.

\section{Referências}

ADORNO, Theodor Consignac Buenos Aires, Amorrortu, 1973.
ADORNO, Theodor, Jutenemciones Caracas, Montevila, 1974

ADORNO, Theodor. Gesummelte Scliniftan. [IX.1]. Frankfurt, Surhkamp, 1975

ADORNO, Theodor Soritti Socologria. Turim, Einaudi, 1976

ADORNO, Theodor. Socologia. Sio Paula, tica, 1986

ADORNO, Theodor. Buig al signo ite los istros, Barcelona, Laia, 1986b.

ADORNO, Theodor. Thr Girther Inithsiny. Iondres, Routledge, 1991.

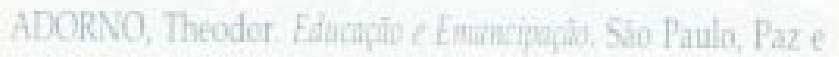
Terra, 1995

ADORNO, Theodor. Intradiccioin of lif scciologit. Barcelona, Gedisa, 1996.

HANSEN, Miram "Mass Culture as Hieroglyphic Writing". In Nen Gernan Gitipie, 56, pp, 43-73, 1992

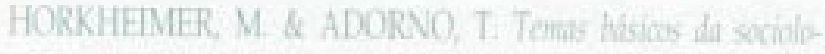
gait. Sio Paulo, Cultrix, 1978

HORKHEIMER, M \& ADORNO, T. Duifeitica de esclarcimente. Rio de laneiro, Zahat, 1965.

HONNETH, Axel. The Critinge of Pourer. Cambridge (MA). MIT Press, 1991.

MARQUES DE MEL 0 , I "Desafíos da pesquisa latino-ame-

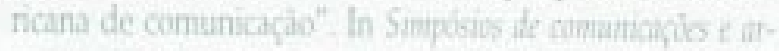
tes. Vol. 5. Sào Paulo, ECA, 1990

MODLESKI, Taria (Ed), Stufics in Entertaimuent. Bloomington, Indiana, Indiana University Press, 1986.

STRINATI, Dominic: An Jitrufuctim to the Theoris of Poprain Griture. Londres, Routledge, 1995

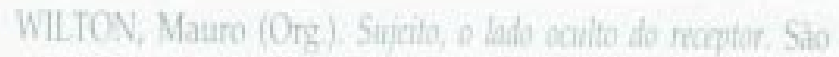
Patilo, Brasiliense, 1995 